\title{
The Relevance of Innocence: Proposition 8 and the Diminished Capacity Defense
}

As part of a sweeping reform of California's criminal justice system, Proposition $8^{1}$ added Penal Code section 25(a), which abolished the "diminished capacity defense." 2 This defense allows a defendant to attempt to show that he could not have had, and therefore did not have, the mental state required for conviction of the crime charged. This Comment contends that prohibiting the admission of evidence demonstrating diminished capacity violates the due process clause of the United States Constitution.

Part I of this Comment examines the diminished capacity defense as it existed prior to section 25(a). ${ }^{3}$ Part II argues that section 25(a) will result in the exclusion of reliable evidence tending to negate the presence of a requisite mental state, and that this exclusion violates the due process clause. The discussion proceeds to examine two limits on the defense: first, the recurring assertion that the diminished capacity defense is limited to specific intent crimes; and second, the requirement

1. "Proposition 8" is the ballot measure denominated "The Victims' Bill of Rights," approved by the voters on June 8, 1982, under the title "Criminal Justice-Initiative Statutes and Constitutional Amendment." Victims' Bill of Rights (Proposition 8), 1982 Cal. Legis. Serv. 1164 (West).

2. Section $\mathbf{2 5}$ of the California Penal Code provides:

(a) The defense of diminished capacity is hereby abolished. In a criminal action, as well as any juvenile court proceeding, evidence concerning an accused person's intoxication, trauma, illness, disease, or defect shall not be admissible to show or negate capacity to form the particular purpose, intent, motive, malice aforethought, knowledge, or other mental state required for the commission of the crime charged.

(b) In any criminal proceeding, including any juvenile court proceeding, in which a plea of not guilty by reason of insanity is entered, this defense shall be found by the trier of fact only when the accused person proves by preponderance of the evidence that he or she was incapable of knowing or understanding the nature and quality of his or her act and of distinguishing right from wrong at the time of the commission of the offense.

(c) Notwithstanding the foregoing, evidence of diminished capacity or of a mental disorder nay be considered by the court only at the time of sentencing or other disposition or commitment.

(d) The provisious of this section shall not be anjended by the Legislature except by statute passed in each house by rollcall vote entered in the journal, two-thirds of the membership in each house concurring, or by a statute that becomes effective only when approved by the electors.

Cal. Penal Code $\$ 25$ (West Supp. 1983).

3. While this Cominent is expressly concerned with Penal Code $\$ 25$ (a) added by Proposition 8, Penal Code $\$ \S 28$ and 29 as amended in 1981 also appear to exclude relevant evidence of diminished capacity and therefore share the constitutional infirmities attributed to section 25 (a). Cal. Penal Code $\$ \S 28-29$ (West Supp. 1983). 
that the defendant's incapacity inust result froin mental illness, mental defect, or intoxication. Part II concludes that both of these linnitations violate the defendant's due process rights. Part III atteinpts to identify soine constitutional means of furthering the purposes of section 25(a).

\section{I The Diminished Capacity "Defense" \\ A. The Diminished Capacity Defense Defined}

The "diminished capacity defense" is a label attached to evidence that the defendant could not, and therefore did not, forn the requisite mental state at the time of the commission of the charged offense. ${ }^{4}$ California courts have received such evidence because " "[a]s a matter of logic, any proof tending to show that a certain inental condition could not exist is relevant and should be admissible to show that it did not exist." "s

The inquiry upon a plea of insamity is very different. Typically, a finding of insanity is not a determination that the crime was not committed because a requisite inental state was lacking. ${ }^{6}$ That society provides for an insanity defense reflects a decision not to hold certam persons accountable for crimes they commit, because they lacked either control over or understanding of their actions to such an extent that it would be unfair to hold them criminally liable. ${ }^{7}$ While some evidence of diminished capacity may also be probative of insanity, the evidence

4. This Comment will use the terminology of "requisite mental state" to emphasize that the choice of a particular mental component varies with the offense charged and that the specified mental state need not imclude an imtention to achieve a particular end.

5. People v. Wetmore, 22 Cal. 3d 318, 324, 583 P.2d 1308, 1312, 149 Cal. Rptr. 265, 269 (1978) (quoting Louisell \& Hazard, Insanity as a Defense: The Bifurcated Trial, 49 CALIF. L. Rev. 804,819 (1961)). The court also cited with approval the opinion of (then Court of Appeal) Justice Kaus in People v. Steel, 237 Cal. App. 2d 182, 190, 46 Cal. Rptr. 704, 709-10 (1965), which "poimted out ... [that] evidence which tends to prove that a defendant could not entertain a certain intent may, when subject to cross-exanmation, convimce the trier of fact that defendant was able to entertain the intent but did not do so on the occasion of the crime." 22 Cal. $3 d$ at 324 n.4, 583 P.2d at 1312 n.4, 149 Cal. Rptr. at 269 n.4.

6. See, e.g., State v. Hebard, 50 Wis. 2 d 408, 420, 184 N.W.2d 156, 163 (1971) (a finding of insanity "is not a finding of inability to intend; it is rather a finding that under the applicable standard or test, the defendant is to be excused from criminal responsibility for lis act.") But see State ex rel Boyd v. Green, 355 So. 2d 789, 792-93 (Fla. 1978) (basis of Florida's msanity defense is that a person is unable to form the requisite intent).

7. Cf. Kadish, The Decline of Innocence, 26 CAMBrudge L.J. 273, 282-83 (1968) (suggesting that the fundanental objection to proposals which would abolish the msanity defense is that they open "to the condemnation of a criminal conviction a class of persons who, on any commonsense notion of justice, are beyond blaming and ought not to be punished."). In California, to be found legally insane, the accused person must demonstrate by a preponderance of the evidence that she was incapable of knowing or understanding the nature and quality of her act and was also incapable of distinguishing right from wrong at the time of the commission of the offense. CAL. PENAL CODE § 25(b) (West Supp. 1983). 
is admitted for entirely different purposes: in the case of diminished capacity, to show that no crime was committed; but in the case of insanity, to show that a criminal should not be punished. ${ }^{8}$

Diminished capacity is also distinct from diminished responsibility. The defense of diminished capacity is not a claim of excuse or mitigation; it relies on a finding that the defendant did not commit the crime charged because he lacked the requisite mental state. In contrast, diminished responsibility is a quasi-insanity defense, a plea in mitigation which does not negate the presence of any eleinent of the crime. Under a diminished responsibility scheme, the defendant is subject to punishment for a lesser offense than that charged because of the presence of niental illness or defect rather than the absence of mens rea. ${ }^{9}$

The application of diminished capacity and diminished responsibility to a strict hability offense illustrates this difference. Such a crime requires no particular inental state. ${ }^{10}$ Therefore, evidence of diminished capacity would not be relevant because the defendant's mental state is not in issue. A mitigating claim of diminished responsibility,

8. This distinction is apparent in California's effort to keep the insanity inquiry distinct from the determination of guilt or innocence by means of a bifurcated trial, with the insanity hearing following only a guilty verdict or a plea of not guilty by reason of insanity. CAL. PENAL CODE $\S \S 1016,1020,1026$ (West 1970 \& Supp. 1983). The distinction has great practical signifcance. The California Supreme Court pointed out in Wetmore that it had repeatedly found evidence offered in unsuccessful insanity pleas to be conclusive on issues of diminished capacity. 22 Cal. 3d at 324-25, 583 P.2d at 1312-13, 149 Cal. Rptr. at 269-70.

9. One author has contended that the "inens rea" model of diminished capacity is indistinguishable from the "mitigation" model of diminished responsibility because under the former "courts began to admit expert testimony which explained why the accused entertained the requisite intent rather than proving its absence." Arenella, The Diminished Capacity and Diminished Responsibility Defenses: Two Children of a Doomed Marriage, 77 CoLum. L. REV. 827, 831 (1977). Even assuming the asserted practice exists, there is no logical reason that a diminished capacity defense must turn into a diminished responsibility claim. In any event, Arenella's observation in no way challenges the validity of this Comment's position that due process requires the admissibility of evidence of diminished capacity.

The defense of diminished responsibility is typically created by statutory provision. See, for example, $\$ 2$ of the English Homicide Act of 1957, which provides, in relevant part:

2.-(l) Where a person kills or is a party to the killing of another, he shall not be convicted of murdcr if he was suffering from such abnornality of mind (whether arising from a condition of arrested or retarded development of mind or any inherent causes or induced by disease or injury) as substantially impaired his mental responsibility for his acts and omissions in doing or being a party to the killing.

...

(3) A person who but for this section would be liable, whether as primcipal or as accessory, to be convicted of murder shall be liable instead to be convicted of manslaughter.

Homicide Act, 5 \& 6 Eliz. 2, ch. 11, \& 2(1), (3) (1957).

For an overview of the various formulations of the diminished capacity defense, see Diminished Capacity-Recent Decisions and an Analytical Approach, 30 VAND. L. REV. 213, 214-20 (1977).

10. See generally W. LAFAVE \& A. Scott, HandBooK on Cruminal LAW § 31, at 218-23 (1972) (discussing strict liability offenses). 
however, could be available because of a societal determination that it is unfair to punish as severely a person who lacks a certain degree of understanding or control of his actions.

\section{B. Development of the Diminished Capacity Defense in California}

In California, the diminished capacity defense is often labeled the "Wells-Gorshen rule." 11 This label refers to two leading cases ${ }^{12}$ that approved the admission of evidence tending to prove that a defendant, by reason of his inental condition, could not form the inental state required for conviction of the crime charged. In neither of these cases did the court suggest that it was creating a special doctrime for the admission of evidence of a defendant's mental or emotional shortcomings. Instead, each court admitted the evidence of a defendant's lack of capacity because of its relevance to the issue of whether or not the defendant had actually entertained the requisite mental state and thus had committed the crime charged. ${ }^{13}$

In People v. Wells, the defendant was a prison inmate charged with assault on a guard, a capital offense requiring inalice aforethought. ${ }^{14}$ The defendant contended that he lacked malice aforethought simce he was reacting to the fear of bodily harn in an honest but unreasonable behef that his action was in self defense. ${ }^{15}$ The California Supreme Court held that it was improper to exclude the defendant's proffered expert testimony to the effect that defendant was in a state of nervous tension at the time of the incident and subject to abnormal fears from even shight stimuli. ${ }^{16}$ The court found that the excluded evidence was material not because it would mitigate the offense, but rather because it would exculpate the defendant by showing that he "would not have committed that particular aggravated offense with which he is charged, for the essential element of 'malice aforethought' would be lacking."17 Wells thus established that "competent evidence, other than proof of sanity or insanity, which tends to show that a (then presumed) legally sane defendant either did or did not in fact possess the required specific intent or motive is admissible."18 Ten years later, in People v. Gor-

11. See, eg., People v. Conley, 64 Cal. 2d 310, 318-19, 411 P.2d 911, 916-17, 49 Cal. Rptr. 815, 820 (1966); People v. Henderson, 60 Cal. 2d 482, 489-90, 386 P.2d 677, 682, 35 Cal. Rptr. 77, 82 (1963).

12. People v. Gorshen, 51 Cal. 2d 716, 336 P.2d 492 (1959); People v. Wells, 33 Cal. 2d 330, 202 P.2d 53 (1949). (1966).

13. People v. Conley, 64 Cal. 2d 310, 316-17, 411 P.2d 911, 915, 49 Cal. Rptr. 815, 819

14. 33 Cal. $2 \mathrm{~d}$ at 334,202 P.2d at 56 .

15. Id at 345,202 P.2d at 62 .

16. Id. at 346,202 P.2d at 62 .

17. Id at 345,202 P.2d at $62-63$.

18. Id at 351,202 P.2d at 66 . 
shen, ${ }^{19}$ the California Supreme Court held that Wells apphed equally to evidence tending to prove that a defendant could not entertam the requisite mental state.

The diminished capacity defense has been available only im limited circumstances. After Wells, the defense was primarily used in homicide cases, ${ }^{20}$ but the list of offenses to which it was applied began to expand. ${ }^{21}$ Eventually, evidence of diminished capacity could be admitted if the defendant was charged with a crime requiring specific but not general intent. ${ }^{22}$ California courts have also implied that the availability of the defense may turn on the cause of the incapacity; they have limited the defense to disabilities derived from mental illness, mental defect, or intoxication. ${ }^{23}$ Thus, if the cause of the diminished capacity were something other than mental illness, mental defect, or intoxication, the defendant would be barred froin making a diminished capacity defense.

\section{The Effect of Proposition 8 on the Diminished Capacity Defense}

Proposition 8 abohshed the diminished capacity defense in California by adding section 25(a) to the California Penal Code. That section states that the defense is abohished and prohibits the introduction of evidence concerning the lack of capacity to forn the requisite mental state. ${ }^{24}$ The summary by the Legislative Analyst is most apt: "The measure would prohibit the use of evidence concerning a defendant's intoxication, trauma, mental illness, disease, or defect for the purpose of proving or contesting whether a defendant had a certain state of mind in connection with the commission of a crime."25

19. 51 Cal. $2 \mathrm{~d}$ at 731,336 P.2d at 502.

20. See, e.g., People v. Mosher, I Cal. 3d 379, 391, 461 P.2d 659, 666, 82 Cal. Rptr. 379, 386 (1969); People v. Conley, 64 Cal. 2d 310, 323, 411 P.2d 911, 919, 49 Cal. Rptr. 815, 823 (1966); People v. Gorshen, 51 Cal. 2d 716, 336 P.2d 492 (1959).

21. In People v. Wetmore, 22 Cal. 3d 318, 331, 583 P.2d 1308, 1317, 149 Cal. Rptr. 265, 274 (1978), the court held that the lack of capacity to form the required mental state could resnlt in acquittal of burglary, and further that the absence of a lesser inclnded offense is irrelevant to apphication of the diminished capacity defense. See also People v. Wilson, 261 Cal. App. 2d 12, 17, 67 Cal. Rptr. 678, 683 (1968) (robbery); People v. Gentry, 257 Cal. App. 2d 607, 610, 65 Cal. Rptr. 235, 238 (1967) (issuing check without sufficient funds).

22. See People v. Drew, 22 Cal. 3d 333, 583 P.2d 1318, 149 Cal. Rptr. 275 (1971) (dictum) (repetition of proposition that availability of diminished capacity defense turns on whether a specific intent crime was charged); People v. Greenfield, 134 Cal. App. 3d Supp. 1, 184 Cal. Rptr. 604 (1982) (applying rule without analysis).

23. E.g., People v. Berry, 18 Cal. 3d 509, 517, 556 P.2d 777, 781-82, 134 Cal. Rptr. 415, 41920 (1976).

24. See supra note 2. See also Brosnahan v. Brown, 32 Cal. 3d 236, 243, 651 P.2d 274, 278, 186 Cal. Rptr. 30, 34 (1982); id. at 262-63, 651 P.2d at 290-91, 186 Cal. Rptr. at 46-47 (Bird, C.J., dissenting) (paraphrasing $\$ 25(\mathrm{a})$ ).

25. California Secretary of State, California Ballot Pamphlet 55 (Primary Election June 8, 1982). 
II

The Diminished CaPacity Defense and the

DEFENDANT'S CONSTITUTIONAL Right TO

Present Evidence Rebutting the

STATE's CASE

\section{A. . The Constitutional Basis of the Diminished Capacity Defense}

As discussed in Part I, the justifieation for the diminished capacity defense is that evidence which tends to show that the requisite mental state could not have existed also tends to show that it did not exist. ${ }^{26}$ This Part argues that as long as the defendant's inental state is an eleinent of the offense, the fourteenth amendment of the United States Constitution prohibits the exclusion of such evidence for two reasons. First, such exclusion violates the defendant's right to present reliable and relevant evidence that is critical to the defense. Second, it effectively reverses the presumption of innocence.

\section{The Right to Present Evidence}

Chambers v. Mississippi ${ }^{27}$ and its progeny have established that due process requires that a defendant be able to present reliable and relevant evidence in his defense notwithstanding rules of procedure and evidence to the contrary. Stating that "few rights are more fundainental than that of an accused to present witnesses in his own defense," 28 the United States Supreme Court lield that a state hearsay rule could not be applied so as to bar testimony that a person other than the defendant had repeatedly confessed to the crime of which the defendant was accused. ${ }^{29}$ While the Court recognized that a defendant's right to present evidence could be limited by appropriate rules of procedure and evidence, ${ }^{30}$ it found that the particular evidence was both reliable and critical to the defense, and that its exclusion violated the defendant's right to an effective defense.

The Court did not indicate whether the constitutional infirmity stemmed froin the exclusionary ruling alone or from the iniproper restriction of the defense's cross-exammation or both. ${ }^{31}$ Subsequent appellate court cases, however, have held that exclusion of reliable, inaterial, and critical evidence is in itself a violation of due process. ${ }^{32}$

\footnotetext{
26. See supra notes $4-5$ and accompanying text.

27. 410 U.S. 284 (1973).

28. Id. at 302 .

29. Id. at $292-93,298,302-03$.

30. Id. at 302.

31. Id.

32. See, e.g., Hughes v. Mathews, 576 F.2d 1250, $1255-59$ (7th Cir.) (exclusion of psychiatric evidence offered to show lack of capacity to form specific intent to kill held a violation of due
} 
For example, a California appellate court, rejecting the prosecution's contention of undue prejudice, held that due process prohibits the exclusion of "evidence that has more than shight probative value to a criminal defendant's defense" where the evidence is vital to his defense. ${ }^{33}$

These decisions indicate that section 25(a) is unconstitutional. It would bar evidence that a defendant's mental condition made him incapable of forming the requisite intent without regard for the reliability or importance of that evidence. ${ }^{34}$ Evidence of diminished capacity is relevant in criminal cases because it "tends to support or rebut the presumption of innocence." ${ }^{35}$ Moreover, evidence which could reasonably

process), cert. dismissed sub nom. Israel v. Hughes, 439 U.S. 801 (1978) (following Chambers); People v. Reeder, 82 Cal. App. 3d 543, 553, 147 Cal. Rptr. 275, 278-81 (1978) (interference with defendant's right to present evidence violates due process) (following Chambers); Vipperman v. State, 96 Nev. 592, 614 P.2d 532 (1980) (due process encompasses accnsed's right to introduce any testimony or documentation which would tend to prove defendant's theory of the case); Commonwealth v. Walzack, $468 \mathrm{~Pa}$. 210, 360 A.2d 914 (1976) (due process requires admission of relevant and competent evidence). $C f$. Phillips v. Wainwright, 624 F.2d 585 (5th Cir. 1980) (due process not violated by exludimg expert opinion on ultimate fact where expert was not barred froin giving testimony on defendant's inental condition and history).

33. People v. Reeder, 82 Cal. App. 3d 543, 553, 147 Cal. Rptr. 275, 278-81 (1978).

34. Section 25(a) excludes evidence that has a particular probative effect, whether or not it is reliable. While some evidence that a defendant might wish to introduce on the issue of his capacity to form a particular mental state may be unrehable, the law already provides for its exclusion on that basis. See, e.g., CAL. Evid. CodE $\$ 352$ (West 1966). See also People v. Kelley, 17 Cal. 3d 24, 30, 549 P.2d 1240, 1244, 130 Cal. Rptr. 144, 148 (1976) (adopting the test of Frye v. United. States, 293 F. 1013, 1014 (D.C. Cir. 1923), for the admission of scientific evidence). But see Bonmie \& Slobogin, The Role of Mental Health Professionals in the United States: The Case for Informed Speculation, 66 V A. L. REv. 427, $464 \mathrm{n} .121$ (1980) (suggesting that it is inappropriate to apply the Frye scientific evidence test to psychiatric evidence). Califorma courts have often noted that such evidence is reliable and probative. See supra notes 11-19. In any event, reliability is best determined on a case-by-case basis.

35. People v. Whitney, 76 Cal. App. 3d 863, 869, 143 Cal. Rptr. 301, 304 (1978). This analysis indicates that $\S 25$ (a) may violate a provision of the state consitution which was also enacted by Proposition 8. Section 28 in article I of the California Consitution provides in relevant part:

Except as provided by statute hereafter enacted by a two-thirds vote of the member-

ship in each house in the Legislature, relevant evidence shall not be excluded in any criminal proceeding. . . . Nothing in this section shall affect any existing statutory rule of evidence relating to privilege or hearsay, or Evidence Code, sections 352, 782 or 1103 .

Nothing in this section shall affect any statutory or constitutional right of the press.

CAL. Const. art. I, § 28(d).

None of the exceptions applies to evidence excluded by $\$ 25$ (a). Section 352 of the Evidence Code, CAL. EviD. CoDE $\$ 352$ (West 1966), gives trial courts discretion to exclude evidence if its probative value is outweighed by the time required to present it or its prejudicial effect. Section 782 of the Evidence Code, CAL. Evid. CODE $\$ 782$ (West Supp. 1983), limits the admissibility of evidence of sexual conduct of the complaining witness in a rape case. Section 1103 of the Evidence Code, CAL. Evid. CODE $\$ 1103$ (West Supp. 1983), excludes certain character evidence. It would be apphicable in the rare event a defendant sought to demonstrate that he lacked the requisite intent by reason of a character disorder short of inental illness, disease, or defect. Thus, it appears that $\S 25$ (a) violates the state constitution.

It may be argued that since $\$ 25$ (a) was contained in the same ballot ineasure that adopted article I, $\S 28$ of the California Constitution, $\$ 25$ (a) should be harmonized with and read as an 
be expected to negate an element of the offense charged, thus resulting in acquittal, must be within any definition of evidence crucial to the defense. To the extent that Penal Code section 25(a) bars such evidence it violates the defendant's right to due process. ${ }^{36}$

\section{Presumptions in Criminal Trials}

In re Winship ${ }^{37}$ and its progeny ${ }^{38}$ have established that due process requires that the state prove beyond a reasonable doubt every fact necessary to constitute the crime charged. Presumptions in criminal cases are permissible only if they do not relieve the state of this burden. ${ }^{39}$ Thus, a state may create a rebuttable presumption and place the bur-

exception to the amendment. The careful specification of exceptions to the "Right-10-Truth-inEvidence" within the text of the amendment itself undermimes this analysis.

36. Fisher v. United States, 328 U.S. 463 (1946), is not to the contrary. In Fisher, a defendant charged with first degree murder in the District of Columbia contended that his "mental and emotional qualities ... were of such a level at the time of the crime that he was incapable of deliberation and premeditation although he was then sane in the usual legal sense." Id. at 466 . The Court held that the trial court had not erred in refusing an instruction specifically directing the jury to consider "the personahity of the [defendant] in determining intent, premeditation and deliberation." Id.

Fisher is distinguishable on two grounds. First, psychiatric evidence of the defendant's capacity was admitted into evidence. The defendant objected that the instructions did not provide the jury adequate guidance to apply it. The majority did not question the defendant's right to present such evidence. $I d$. at 467 . Thus, the due process right to present evidence was not implicated.

Second, the defendant did not argue that the diminished capacity defense was constitutionally required, but rather that it should be adopted as a coinnon law rule for the District of Columbia. This left the Court free to defer to Congress and the lower courts on a matter of local criminal law. Id. at $476-77$. The suggested constitutional challenge to $\$ 25$ (a) raises no such issues of local law.

Further, local law has changed since Fisher. In United States v. Brawner, 471 F.2d 969 (D.C. Cir. 1972) (en banc), the District of Colunbia Circuit recognized both the admissibility of evidence of abnormal inental condition to negate the presence of a requisite mental state and the need for proper jury instructions, overruling their decision in Fisher, 149 F.2d 28 (D.C. Cir. 1945). It is well settied that under the California Constitution the jury must be instructed upon a theory of diminished capacity when there is evidence in support of such theory. CAL. CoNST, art. VI, § 15; People v. Morse, 70 Cal. 2d 711, 732, 736, 452 P.2d 607, 619, 622, 76 Cal. Rptr. 391, 403, 406 (1969); People v. Modesto, 59 Cal. 2d 722, 729-31, 382 P.2d 33, 37-38, 31 Cal. Rptr. 225, 229-30 (1963); Pcople v. Carmen, 36 Cal. 2d 768, 773, 228 P.2d 281, 284 (1951). Fisher should not be revived to exclude relevant evidence of a defendant's innocence of a crime charged now that its basis in local law is gone. See also Taylor, Partial Insanity As Affecting the Degree of Crime-A Commentary on Fisher v. Uuited States, 34 CALIf. L. REv. 625 (1946); Weihofen \& Overholser, Mental Disorder Affecting the Degree of a Crime, 56 YALE L.J. 959 (1947).

37. 397 U.S. 358, 364 (1970). Winship involved a New York Family Court finding of juvenile delinquency which was supported only by a preponderance of the evidence. Id. at 360 . The Court, reversing the adjudication of delinquency, held that due process prohibits a criminal conviction that is not supported by "proof beyond a reasonable doubt of every fact necessary to constitute the crime . . . charged." Id. at 364 .

38. See, e.g., Jackson v. Virginia, 443 U.S. 307, 315 (1979).

39. See, e.g., id. at 316; Patterson v. New York, 432 U.S. 197, 205-06 (1977); Mullaney v. Wilbur, 421 U.S. 684, 685 (1975); In re Winship, 397 U.S. 358, 364 (1970); Jeffries \& Stephan, Defenses, Presumptions, and Burden of Proof in the Criminal Law, 88 YALE L.J. 1325 (1979). 
den upon the defendant so long as he is not required to bear the burden of proving the nonexistence of any of the elements of the crime ${ }^{40} \mathrm{Be}-$ cause the state must bear the burden of proof on all elements of the crime, it cannot create even a rebuttable presumption that one of these elements exists.

Section 25(a) creates a conclusive presumption of capacity. Capacity to entertam the requisite mental state is not an element of a crime ${ }^{41}$ However, the United States Supreme Court has indicated that the Constitution prohibits the use of presumptions under certain circumstances, even when the presumption does not establish an element of the crime. In Patterson v. New York, ${ }^{42}$ the Court upheld the use of rebuttable presumptions with regard to an affirmative defense, but intimated that there were constitutional limits upon the use of such presumptions. The Court found it important that the presumptions in question had been used at common law and had not led "to such abuses or to such widespread redefinition of crime and reduction of the prosecution's burden that a new constitutional rule was required." ${ }^{\text {"43 }}$ Nor was their " purpose or effect . . . to unhinge the procedural presumption of innocence . . . " "44 This imdicates that some presumptions, even if rebuttable, would violate due process.

The conclusive presumption created by section 25(a) is precisely the abuse of which the Court warned, simce it effectively reverses the presumption of innocence. Once the act has been proven or admitted by the defendant, California law allows the jury to infer that the defendant had the requisite intent. ${ }^{45}$ The logic supporting this inference in the nornial case is so strong that the inference of intent follows from proof of the prohibited conduct almost automatically. If the defendant is precluded from demonstrating that he suffered from diminished ca-

40. Patterson v. New York, 432 U.S. 197, 205-09, 211 (1977). There is, of course, the additional requirenent recognized in Tot v. United States, 319 U.S. 463, 467 (1943), that there be a rational connection between the facts proved and the fact presunied.

41. This is nade clear both by the first sentence of $\$ 25(a)$ which expressly abolishes the diminished capacity defense and by those decisions which recognized the defense, not because capacity was an elemeut, but because it tended to negate the mental state elenient. See supra text accompanying notes 11-19. But see Jeffies \& Stephan, supra note 39 (critiquing efforts to recast elements of crime as defenses).

42. 432 U.S. 197 (1977).

43. Id. at 211 .

44. Id at 211 n.13 (quoting People v. Patterson, 39 N.Y.2d 288, 305-07, 347 N.E.2d 898, $909-$ 10, 383 N.Y.S.2d 573, 584 (1976) (Breitel, C.J., concurring), aff'd sub nom. Patterson v. New York, 432 U.S. 197 (1977)).

45. "The intent or intention is nuanifested by the circumstances connected with the offense." Cal. Penal CODE $\$ 21$ (a) (West Supp. 1983). "Accordingly, the required intent is almost invariably an inference drawn from circumstantial evidence." 1 B. WITKIN, California CrIMEs $\$$ 53(4) (1963). A defendant's mental condition is a circumstance connected with the offense, but if such evidence is excluded the circumstances will be limited to inaterial such as the admitted conduct. 
pacity the jury will almost inevitably take the next step and infer the presence of the requisite inental state. The bar on evidence of diminished capacity thus not only creates a presumption of capacity, but also amounts to a presumption of the presence of the requisite mental state. $^{46}$ This demonstrates that capacity is so tightly bound up with the mental state element of the crime that to deny a defendant the right to show he lacked capacity "unhinges" the presumption of innocence.

The Uinted States Supreme Court's civil cases also illustrate that conclusive presumptions are constitutionally suspect. The Court has held that when a fundamental interest is affected by some threatened state action, the state may not set up an irrebuttable presumption of the facts upon which its action is predicated. ${ }^{47}$ For example, in Vlandis $v$. Kline, ${ }^{48}$ the state offered reduced tuition rates to state residents, but used a conclusive presumption that the non-resident status of a student at the time of application contimued for the entire time of attendance. ${ }^{49}$ The Court held that due process is violated when the person affected by the finding is prohibited from presenting evidence that will controvert the presumption set up by the state. ${ }^{50}$

Section 25(a) violates this standard because it prevents a defendant from rebutting the presumption that he had capacity to form the requisite mental state. The interest of a criminal defendant in his herty is certainly a fundamental right. ${ }^{51}$ Therefore, it is mconsistent with due

46. Once prohibited from presenting evidence of incapacity, a defendant who lacked the requisite mental state by reason of incapacity may only combat the inference of mental state drawn from the circumstances by simply denying that he actually entertained the requisite mental state. This denial is useless to the defendant; no jury would give such a self-serving clain any credence. Thus section 25(a)'s absolute exclusion of evidence of incapacity amounts to a de facto irrebutable presumption of the requisite mental state when considered in conjunction with the inference of mental state that will inevitably be drawn from proof of the actus reus, proof which is not disputed by the diminished capacity defendant. Applying a similar analysis, the Seventh Circuit has held that mstructing the jury that all persons are presuuned to have intended the consequences of their acts unless facts or circumstances rebut the presumption and then excluding psychiatric evidence of diminished capacity set up a conclusive presumption of the requisite mental state which unconstitutionally relieved the state of its burden of proving all elements of the crime beyond a reasonable doubt. Hughes v. Mathews, 576 F.2d 1250, 1254-55 (7th Cir. 1978), cert. dismissed sub nom. Israel v. Hughes, 439 U.S. 801 (1978). See also State ex rel. Boyd v. Green, 355 So. 2d 789, 794 (Fla. 1978) (statute excluding evidence of inabihty to form requisite intent from guilt phase of bifurcated trial violates due process as it creates an irrebutable prestimption of imtent).

47. Cleveland Bd. of Educ. v. LaFleur, 414 U.S. 632, 644 (1974); Vlandis v. Kline, 412 U.S. 441,446 (1973); Stanley v. Illinois, 405 U.S. 645, 652, 658 (1972). $C f$. Weinberger v. Salf, 422 U.S. 749, 771-74 (1975) (Vandis does not apply when the interest affected by the presumption is a mere "non-contractual claim to receive funds from the public treasury.").

48. 412 U.S. 441 (1973).

49. Id. at $442-43$.

50. Id. at $445-47$.

51. See United States v. Thoinpson, 452 F.2d 1333, 1340 (D.C. Cir. 1971), cert. denied, 405 
process to deny a defendant the right to rebut a presumption that he had capacity.

\section{The Constitutional Roots of California's Diminished Capacity Defense}

The California Supreme Court's cases are consistent with this Comment's constitutional analysis. In the leading cases of People v. $W^{2} l l s^{52}$ and People v. Wetmore, ${ }^{53}$ the court considered issues similar to those posed by section 25(a). In both, it was urged that a statute prohibited admission of evidence of diminished capacity. ${ }^{54}$ The courts rejected this argument, implying that such a construction would be inconsistent with the constitutional guarantee that the government bear the burden of proof and with the defendant's corresponding right to present evidence in rebuttal.

Both cases alluded to the defendant's right to present evidence. In Wells, the state argued that California's statutory scheme for separate trials of the issues of guilt and sanity made evidence of diminished capacity inadmissible at the guilt phase. The court implied that adoptimg this argument would violate due process. The court rejected the state's argument, reasoning that it would presume neither that the Legislature intended to deny a defendant the right to produce competent evidence to show his innocence, nor that the Legislature sought to delete an element of due process. ${ }^{55}$

Similarly, in Wetmore the court rejected the state's argument that because the issues of sanity and guilt are tried separately, the evidence of diminished capacity was inadmissible when it was also proof of insanity. The court suggested that such a construction of the statute would violate a defendant's constitutional right to present evidence in his defense, stating that the "defendant cannot logically or constitutionally be denied the right to present probative evidence rebutting an element of the crime merely because such evidence also suggests insanity." 56

There are also suggestions in both Wells and Wetmore that excluding evidence of the defendant's imcapacity would impermissibly shift

U.S. 998 (1972); Bell v. Hongisto, 346 F. Supp. 1392, 1394-96 (N.D. Cal. 1972), cert. denied, 420 U.S. 962 (1975).

52. 33 Cal. 2d 330, 202 P.2d 53 (1949).

53. 22 Cal. 3d 318, 583 P.2d 1308, 149 Cal. Rptr. 265 (1978).

54. Wells, 33 Cal. 2d at 343-46, 202 P.2d at 61-63 (1949); Wetmore, 22 Cal. 3d at 329-30, 583 P.2d at 1316, 149 Cal. Rptr. at 273 (at issne in Wetmore was dictum in Wells regarding the statutory bifurcation scheme's exclusion from the guilt phase of evidence amounting to proof of insarity).

55. 33 Cal. $2 \mathrm{~d}$ at $354-55,202$ P.2d at 68 .

56. 22 Cal. 3d at 321, 583 P.2d at 1310, 149 Cal. Rptr. at 267. 
the burden of proof. In Wells, the court recognized that if it were to prohibit all evidence of diminished capacity until the issue of sanity was tried, evidence of diminished capacity that was not relevant to insanity would never be admitted. The court likened such a rule to an impermissible conclusive presumption, because the prosecution would still be able to introduce evidence of imtent. The court said, "To make a presumption of a factual element of guilt conclusive at all stages of the trial, or to preclude the defendant absolutely and at all stages from meeting proof of an element of guilt adduced by the prosecution, cannot be sustained."s7

In Wetmore, it was argued that evidence of diminished capacity that was also relevant to show insanity should not be admissible during the guilt phase of trial. The court noted that the state bears the burden of proof on all elements of the crime, and then said, "To deny the defendant the opportumity to present [evidence of diminished capacity] at a time when the state still bears the burden of proof beyond a reasonable doubt may deny him due process of law."158

\section{B. Judicial Limitations on the Admission of Evidence of Diminished Capacity}

It is generally understood ${ }^{59}$ that the defense of diminished capacity is not available for general intent crimes or when the source of the incapacity is something other than mental defect, disease, or intoxication. This Comment's analysis implies that such limitations would violate the defendant's constitutional rights.

\section{The Limitation of the Diminished Capacity Defense to Specific Intent Crimes}

Under California law, diminished capacity is said to be a defense to crimes requiring specific intent but not to crimes requiring only general intent. ${ }^{60}$ For purposes of the diminished capacity defense, however, general intent crimes are constitutionally indistinguishable from specific intent crimes. ${ }^{61}$ By statute, inental state is an element of both

57. $33 \mathrm{Cal} .2 \mathrm{~d}$ at 346,202 P.2d at 63 (emphasis in original).

58. 22 Cal. $3 \mathrm{~d}$ at 327 n.6, 583 P.2d at 1314 n.6, 149 Cal. Rptr. at 271 n.6.

59. The authority of the leading cases which appear to support these limitations is questioned at infra notes 68-70.

60. People v. Drew, 22 Cal. 3d 333, 344, 583 P.2d 1318, 1323, 149 Cal. Rptr. 275, 280 (1978); People v. Greenfield, 134 Cal. App. 3d Supp. 1, 3, 184 Cal. Rptr. 604, 605 (1982).

61. See infra notes 62-64 and accompanying text. These arguments do not rely on agreement that a particular mental problem tends to make certain imdividuals incapable of forming the mental state associated with a particular general imtent crime. The contention is only that if such evidence exists it may not constitutionally be excluded on the basis of a distinction between general and specific intent crimes. 
specific and general intent crimes. ${ }^{62}$ Thus, the state inust prove that the defendant did the proscribed act with the requisite inental state, ${ }^{63}$ whether that inental state is labeled "general intent" or "specific intent." Therefore, if exclusion of reliable evidence of diminished capacity violates due process when a specific intent crime is charged, exclusion of such evidence results in the saine violation when a general intent crime is charged, since the state bears the same burden in both situations. $^{64}$

Moreover, the distinction between specific and general intent is analytically untenable. This inakes the exclusion of evidence of diminished capacity for general intent crimes even less defensible. Courts and commentators have long recognized that it is extrennely difficult to provide any rational basis for distinguishing between crimes requiring specific and general intent. ${ }^{65}$ Courts wrestling with this problein have failed to produce a coherent distinction. ${ }^{66}$ Furthermore, the Model Pe-

62. Cal. Penal Code $\$ 20$ (West 1970).

63. 1 California JURy Instructions-Criminal $\$ 3.30$ (West 4 th rev. ed. 1979) [hereinafter cited without cross-reference as CALJIC].

64. As the mental state termed "general intent" is an element of the crime charged, the state bears the burden of proving the presence of general intent beyond a reasonable donbt; the defendant must be permitted to rebut the state's case. See supra notes 27-46 and accompanying text.

65. For example, in People v. Hood, 1 Cal. 3d 444, 462 P.2d 370, 82 Cal. Rptr. 618 (1969), the Califormia Supreme Court cited favorably the suggestion in J. Hall, General Principles of Criminal Law 142 (2d ed. 1960) and G. Williams, Criminal Law-The General Part § 21, at 49 (2d ed. 1961), that the categorizations "specific" and "general" intent be abolished. 1 Cal. 3d at $456-57,462$ P.2d at 377-78, 82 Cal. Rptr. at $625-26$.

66.

Specific and general intent have been notoriously difficult terms to define and apply, and a number of textwriters recommend that they be abandoned altogether. Too often the characterization of a particular crime as one of specific or general intent is determined solely by the presence or absence of words describing psychological phenomena"intent" or "malice," for example-in the statutory language of defining the crime. When the definition of a crime consists of only the description of a particular act, without reference to intent to do a further act or achieve a future consequence, we ask whether the defendant intended to do the proscribed act. This intention is deeined to be a general criminal intent. When the definition refers to defendant's intent to do some further act or achieve some additional consequence, the crime is deemed to be one of specific intent. There is no real difference, however, only a linguistic one . . .

People v. Hood, 1 Cal. 3d 444, 456-57, 462 P.2d 370, 377-78, 82 Cal. Rptr. 618, 625-26 (citations omitted).

The California law of homicide illustrates the inadequacy of this definition. Neither premeditation nor makice aforethought can be described in terms of "intent to do some further act or achieve some additional consequence," although both are part of the "specific intent" of first degree murder. "Premeditation" encompasses the defendant's ability to "maturely and meaningfully reflect upon the gravity of his contemplated act." People v. Wolf, 61 Cal. 2d 795, 821, 394 P.2d 959, 975, 40 Cal. Rptr. 271, 287 (1964) (emphasis in original). "Malice aforethought" is a mental state regarding an act comprised of a "wanton disregard for human life or antisocial inotivation." People v. Conley, 64 Cal. 2d 310, 322, 411 P.2d 911, 918, 49 Cal. Rptr. 815, 822 (1966). It requires an awareness that society expects the defendant to act in "conformity to a different standard." People v. Flannel, 25 Cal. 3d 668, 679, 603 P.2d 1, 7, 160 Cal. Rptr. 84, 90 (1980). "Malice aforethought" is also commonly defined in terms of the absence of those incntal states which are 
nal Code recommends that the distinction be abandoned altogether. ${ }^{67}$ This suggests that the labels specific and general intent are likely to be apphed arbitrarily. ${ }^{68}$ It is offensive to have important constitutional rights turn on an unprincipled distinction. ${ }^{69}$

\section{The "Limitation" of the Diminished Capacity Defense to Incapacity from Mental Illness, Defect, or Intoxication}

People $v$. Berry held that evidence of diminished capacity is admissible only when the source of the imcapacity is "mental illness, mental defect or mtoxication."70 As with the apparent limitation to specific

understood to negate its presence, sucls as "heat of passion" or "honest belief of imminent peril." Id. at $675-80,603$ P.2d at 4-7, 160 Cal. Rptr. at 87-90.

Finally, the gravity of the offense is not determinative of the decision to label the requisite intent "specific" as opposed to "general." For example, the federal offense of aircraft piracy, 49 U.S.C. $\$ 1472$ (1976 \& Supp. V 1981), is a general intent crime, see, e.g., United States v. Busic, 592 F.2d 13, 21 (2d Cir. 1978).

67. MODel PeNal CODE $\S \S 2.02,4.02$ (Proposed Official Draft 1962); id. $\$ 2.02$ comments 12 , at 124 (Tent. Draft. No. 4, 1955).

68. This determination of which label to apply to the requisite mental state should not be confnsed with the determination as to what mental state is to be required. For example, People v. Nance, 25 Cal. App. 3d 925, 102 Cal. Rptr. 266 (1972), defined arson as requiring only that the prohibited fire be set deliberately. Id. at 930, 102 Cal. Rptr. at 269-70. Since pyromania would not interfere with the capacity to intend to set a fire, the decision rendered evidence of pyromania irrelevant. However, the application of the label "general intent" as opposed to "specific intent" was essentially arbitrary. Similarly, People v. Hood, 1 Cal. 3d 444, 462 P.2d 370, 82 Cal. Rptr. 618 (1969), questioned the substance of the distinction between general and specific intent, see supro notes 65 \& 66, yet decided that evidence of intoxication could be excluded when assault was charged on the basis that " $a$ drunk unan is capable of forming an intent to . . strike another." Id. at 458,462 P.2d at 379,82 Cal. Rptr. at 627 .

69. People v. Noah, 5 Cal. 3d 469, 487 P.2d 1009, 96 Cal. Rptr. 441 (1971), is questionable authority for such an abrogation of a defendant's constitutional rights. In Noah, the court rejected the argument that evidence of diminished capacity can negate intent by reading Act of Apr. 16, 1850 , cl. 99, $\$ \S 2,3,1850$ Cal. Stat. 229, 229 (current version at CAL. PeNAL Code $\$ 21$ (West Supp. 1983)), to allow such negation only by evidence of "idiocy," "lunacy," or "insanity." 5 Cal. 3d at 477-78, 487 P.2d at 1014-15, 96 Cal. Rptr. at 446-47. This novel construction confiicts with Gorshen (a nnatter the Noah court ignored), and is equally at odds with the common construction of $\S 21$ as merely permitting an inference of intent from circumstantial evidence. 1 B. WITKIN, supra note $45, \S 53(4)$. This opinion also evimces some confusion between insanity and diminished capacity. 5 Cal. 3d at 478, 487 P.2d at 1015, 96 Cal. Rptr. at 447 . Moreover, the constitutional limits on the use of $\S 21$ as it was construed in Noah were not directly faced since $\$ 21$ was not applied there to exclude evidence nor was the jury instructed that capacity to form general intent should be conclusively presumed. See Comment, Rethinking the Specific-General Intent Doctrine in Callfornia Criminal Law, 63 CALIF. L. REv. 1352, 1373-74 (1975).

70. 18 Cal. 3d 509, 517, 556 P.2d 777, 781, 134 Cal. Rptr. 415, 419 (1976) (emphasis oinitted). Berry did not imdependently analyze the purported limitation but rather assumed that it had been established by prior case law. Id. However, the authority relied upon in Berry never purported to hold this. See People v. Castillo, 70 Cal. 2d 264, 270, 449 P.2d 449, 452, 74 Cal. Rptr. 385, 388 (1969), cert. denied, 397 U.S. 944 (1970); People v. Morse, 70 Cal. 2d 711, 735-36, 452 P.2d 607, 621, 76 Cal. Rptr. 391, 405 (1969); People v. Conley, 64 Cal. 2d 310, 322, 411 P.2d 911, 918, 49 Cal. Rptr. 815, 822 (1966). Castillo approved a jury instruction that "Inental illness, imtoxication or any other cause" could negate the requisite mental state. 70 Cal. $2 \mathrm{~d}$ at $268-69,449$ P.2d at 451,74 Cal. Rptr. at 387. Accord Morse, 70 Cal. 2d at 731 n.12, 452 P.2d at 618 n.12, 76 Cal. Rptr. at 402 n.12 
intent crimes, this restriction is inconsistent with due process. The question should be not why, but whether, the defendant lacked capacity. A defendant suffering from diminished capacity could not forn the requisite inental state and therefore did not commit the crime, regardless of the cause of his incapacity. Exclusion of evidence that would prove that the defendant did not commit the crime is inconsistent with the defendant's constitutional rights.

The rule becomes even less appealing when one considers its effects. For example, the inental impairment caused by the trauma of an accident might not amount to mental illness or defect. If so, this rule would prevent the traumatized accident victim from showing that he lacked the requisite inental state and could not have committed the crime. In contrast, one who voluntarily becomes intoxicated could show that he was suffering from diminished capacity. Drawing such a distinction seems contrary to our fundamental notions of fairness. ${ }^{71}$

\section{III}

\section{The Diminished Capacity Defense: Suggested Approaches to Popularized Pleas}

The passage of Proposition 8 indicates the public's fear of rising crime and the concomitant unpopularity of the diminished capacity defense. The wide-ranging reforins of the measure answered a felt need for improvement of the criminal justice system. This Part will argue that a constitutionally grounded diminislied capacity defense can coexist with a strong penal systein. Section A will demonstrate that section

(instruction modified to refiect evidence actually profferred). In addition, California's approved jury instruction that the source of the incapacity could be "abnormal mental or physical condition, however caused," was not changed to conforn with Berry. I CALJIC $\$ 3.35$ (West 4th rev. ed. 1979) (withdrawn in 1982, 1 CALJIC $\$ 3.35$ (West Supp. 1982)). In addition, Berry permitted the defendant to introduce all the evidence which went to diminished capacity in order to prove provocation. $18 \mathrm{Cal}$. 3d at 514, 556 P.2d at 780, 134 Cal. Rptr. at 418 . Thus, the court's discussion of diminished capacity was dicta since it was immaterial to the admission of the proffered evidence.

Further, there is some question whether Berry is still good law. People v. Flannel, $25 \mathrm{Cal} .3 \mathrm{~d}$ 668, 603 P.2d 1, 160 Cal. Rptr. 84 (1980), although not a diminished capacity decision, appeared to recognize that the criterion for admissibility is whether the proffered evidence tends to negate the presence of the requisite mental state and not what condition or events produced the evidence. The court held that an unreasonable and mistaken but honest behef in the need for self defense negates inalice aforethought, whether or not that belief stemmed from an abnornal physical or mental condition. Id. at 678-79, 603 P.2d at 6-7, 160 Cal. Rptr. at 89-90.

71.

Neither logic nor justice can tolerate a jurisprudence that defines the elements of an offense as requiring a mental state such that one defendant can properly argue that his voluntary drunkenness removed his capacity to form the specific intent but another defendant is inhibited from a submission of his contention that an abnormal mental condition, for which he was in no way responsible, negated his capacity to form a particular specific intent ....

United States v. Brawner, 471 F.2d 969, 999 (D.C. Cir. 1972) (en banc). 
25(a) does not meet its goals, and Section B will discuss constitutional ways of reaching those ends.

\section{A. Justifications for Penal Code Section 25(a)}

The California Supreme Court recently noted that the purposes of Proposition 8 were "achieving more severe punishinent for, and more effective deterrence of, criminal acts"; "protecting the public from the preinature release into society of criminal offenders"; "providing safety from crime to . . . school pupils and staff"; and "assurnig restitution for the victims of criminal acts." 72 Of these purposes, only the goals of severe punishinent, effective deterrence, and the avoidance of the premature release of dangerous persons are arguably served by abolishing the diminished capacity defense. None of these would be frustrated by the diminished capacity defense.

The goal of punishınent is not properly advanced by prohibiting a defendant who lacked the capacity to form the requisite intent from proving his incapacity. Exclusion of diminished capacity evidence means that innocent defendants (i.e., those who lacked the requisite mental state) are more likely to be punislied. A just penal system would punisli only the guilty.

Neither is the goal of deterrence furthered by eliminating the diminished capacity defense. Only voluntary acts and thoughts can be deterred, and capacity is entirely involuntary. Therefore, persons actually lacking capacity are not likely to be deterred.

Nor is the problein of preinature release appropriately solved by abolishing the diminished capacity defense. California law insists that only guilty persons (i.e., those who acted with the requisite mental state) be convicted of crimes, ${ }^{73}$ thus, innocent persons cannot be released too early, since they have committed no crime. Sucli innocent persons may still be dangerous, since their acts can cause harm whatever the mental state of the actor, but persons who are dangerous in this sense do not belong in the criminal justice systein.

If a pumishment or deterrence purpose can be attributed to section 25(a), it must be founded in the fear that persons with capacity will be able to "fool" the jury and "get away with" crime by claiming incapacity. Both this concern and the fear of the release of dangerous persons due to the diminisled capacity defense are better addressed directly than by an unconstitutional interference with the trial process. The next Section will discuss these direct means.

72. Brosnahan v. Brown, 32 Cal. 3d at 247, 651 P.2d at 280, 186 Cal. Rptr. at 36.

73. Cal. Penal Code $\$ 20$ (West 1970). 


\section{B. Suggested Solutions to Implement Section 25(a)'s Purposes}

\section{The Problem of Jury Error}

Fears that nonmeritorious claims of incapacity will be successful can best be addressed on a case by case basis rather than by wholesale conviction of the innocent to deter the guilty. Well-informed inquiry by the trial court and counsel into the relevance and rehability of the proffered evidence, and clear jury instructions are recognized means, consistent with due process, of combatting jury error.

Not all psychiatric or psychological testimony attempting to reconstruct the defendant's mental state at the time of the charged conduct is equally rehable. Better guidance and education of trial judges in this area could improve the accuracy of courts' evaluations of the reliability of proffered evidence of diminished capacity. Professors Bonnie and Slobogin, proponents of the admission of expert testimony on the issue of mens rea in criminal trials, suggest that judges be more careful when deciding whom they qualify as expert witnesses. Specifically, they recommend that experts, in addition to being well-qualified in their field, also have a firm understanding of the substantive law. Furthermore, because the usefulness and reliability of a psychiatric evaluation depends largely on the evaluation itself, they recommend that the expert not be permitted to testify unless he has performed a thorough evaluation of the defendant which is designed to learn the answers to the precise questions on which the expert will be called to testify. ${ }^{74}$

The trial court's evaluation of the relevance of proffered evidence of diminished capacity might also be improved. Psychiatric or psychological evidence is not necessarily evidence of diminished capacity. The task for the trier of fact is to determine the presence or absence of a requisite mental state at the time certain conduct occurred. The trial court must ask whether the proferred expert testimony, if true, makes it either more or less likely that the defendant had the requisite mental state at the pertinent time. Careful attention must be given to the particular requisite mental state mvolved as well as to the expert testimony.

Well-informed and prepared cross-exammation is the traditional tool used to aid the jury in making their determination of reliability. The efficacy of cross-examination could be improved by requiring that a defendant give notice, $m$ advance of trial, of his intention to present evidence of diminished capacity. ${ }^{75}$ When expert testimony is inet with

74. Bonnie \& Slobogin, supra note 34 , at 457-61 \& nn.103-09.

75. Such a provision for notice could be modeled on the Federal Rules of Criminal Procedure which require a defendant to give notice in advance of trial that certain theories of defense based upon mental condition will bo presented at trial. FED. R. CRIM. P. 12.2. 
effective cross-examination, the jury is likely to reject a defense expert's testimony as to the defendant's mental state even if the prosecution puts on no expert testimony at all. ${ }^{76}$

\section{The Problem of Protecting Society from Presently Dangerous Persons}

The final concern is that a severely disturbed or dangerous person could be released into society if the diminished capacity defense results in his acquittal. Abohshing the diminished capacity defense is an illfashioned and madequate response to this problem, since dimimished capacity has nothing to do with present dangerousness. Some defendants will not pose a threat by the time of trial. Their incarceration for crimes they did not commit will serve no one. Just as importantly, persons whose mental conditions make them potential recidivists will not be identified and will be released as a matter of course after serving their sentences. Civil commitment procedures can remedy the premature release problem with much greater precision.

The provisions for civil commitment directly addrcss the person who, "as a result of mental disorder, is a danger to others."77 These provisions perimit a judge of the county where a prisoner is confined to institute evaluation and treatment procedures at any time during the prisoner's confinement. ${ }^{78}$ Such evaluation and treatment procedures could be made autoinatic in the case of any person who is acquitted after presenting a diminished capacity defense. The prisoner inay be detained for an initial period of up to seventy-two hours for treatinent and evaluation. ${ }^{79}$ At the end of that period, the prisoner may be confined for up to fourteen more days of treatment if the staff of the seventy-two-hour facility certifies that he is a danger to others because of mental disorder. ${ }^{80}$ After the fourteen-day period, the prisoner could be confined for up to 180 days if he has sufficiently manifested his dangerousness. ${ }^{81}$ With such direct solutions available, the availability of the

76. On the jury's discretion to disregard expert testimony, see, for example, People v. Drew, 22 Cal. 3d 333, 350-51, 583 P.2d 1318, 1327-28, 149 Cal. Rptr. 275, 284-85 (1978), and People v. Wolff, 61 Cal. 2d 795, 804, 394 P.2d 959, 964, 40 Cal. Rptr. 271, 276 (1964).

77. Cal. Welf. \& INST. CODE $\S 5150$ (West Supp. 1983).

78. Cal. Penal Code $\$ 4011.6$ (West 1982).

79. CAL. Welf. \& INST. CODE $\$ 5150$ (West Supp. 1983).

80. Id. $\S 5250$.

81.

At the expiration of the 14-day period of intensive treatment, a person may be confined for further treatment pursuant to the provisions of this article for an additional period, not to exceed 180 days if he or she:

(a) Has attempted, inflicted, or made a substantial threat of physical harm upon the person of another after having been taken into custody, and while in custody, for evalua- 
diminished capacity defense poses no real threat of releasing dangerous persons into society.

\section{CONCLUSION}

Opposition to the diminished capacity defense has probably resulted from a misunderstanding of its basis. Unlike the insanity defense, it does not operate to free unfortunate but guilty persons. Rather, it is a way of proving that the defendant lacked the mental state that is required for conviction of a crime. Properly understood, the defense is not a trick that allows criminals to avoid deserved punishment, but a constitutionally required tool for preventing the conviction of those innocent of the crime charged.

There still may be legitimate concerns regarding the reliability of dimimished capacity evidence and the possibility that dangerous persons will obtain release by virtue of the defense. As this Comment has pointed out, however, these concerns can be addressed without the infringement of due process and convictions of innocent people which abolition of the diminisleed capacity defense necessarily entails.

Frederic Ron Krausz*

tion and treatment, and who, as a result of mental disorder, presents a demonstrated danger of substantial physical harm to others. or

(b) Had attempted, or inflicted physical harm upon the person of another, that act having resulted in his or her being taken into custody and who presents, as a result of mental disorder, a demonstrated danger of substantial physical harm to others. Id. $\S 5300$.

- B.A. 1978, Yale University; J.D. 1983, Boalt Hall School of Law, University of California, Berkeley. 